\title{
The carbon budget of the North Sea
}

\author{
H. Thomas ${ }^{1}$, Y. Bozec ${ }^{2}$, H. J. W. de Baar ${ }^{2}$, K. Elkalay ${ }^{2}$, M. Frankignoulle ${ }^{3}$, L.-S. Schiettecatte ${ }^{3}$, G. Kattner ${ }^{4}$, and \\ A. V. Borges ${ }^{3}$ \\ ${ }^{1}$ Canada Research Chair, Dalhousie University, Department of Oceanography, 1355 Oxford Street, Halifax, Nova Scotia B3H \\ 4J1, Canada \\ ${ }^{2}$ Royal Netherlands Institute for Sea Research (NIOZ), P.O. Box 59, 1790 AB Den Burg, Texel, The Netherlands \\ ${ }^{3}$ Chemical Oceanography Unit, MARE, University of Liège, Institut de Physique (B5), 4000 Liège, Belgium \\ ${ }^{4}$ Alfred Wegener Institute for Polar and Marine Research, Am Handelshafen 12, 27570 Bremerhaven, Germany
}

Received: 26 July 2004 - Published in Biogeosciences Discussions: 17 August 2004

Revised: 19 January 2005 - Accepted: 17 February 2005 - Published: 7 March 2005

\begin{abstract}
A carbon budget has been established for the North Sea, a shelf sea on the NW European continental shelf. The carbon exchange fluxes with the North Atlantic Ocean dominate the gross carbon budget. The net carbon budget more relevant to the issue of the contribution of the coastal ocean to the marine carbon cycle - is dominated by the carbon inputs from rivers, the Baltic Sea and the atmosphere. The North Sea acts as a sink for organic carbon and thus can be characterised as a heterotrophic system. The dominant carbon sink is the final export to the North Atlantic Ocean. More than $90 \%$ of the $\mathrm{CO}_{2}$ taken up from the atmosphere is exported to the North Atlantic Ocean making the North Sea a highly efficient continental shelf pump for carbon.
\end{abstract}

\section{Introduction}

During the last decade many efforts have been made to investigate, understand and quantify the global carbon cycle, since the greenhouse gas carbon dioxide $\left(\mathrm{CO}_{2}\right)$ plays a key role in controlling climate on Earth. It has also been realised that the $\mathrm{CO}_{2}$ released by human activities is in part responsible for global warming by affecting the heat balance on Earth (IPCC, 2001). Large international projects such as the World Ocean Circulation Experiment (WOCE) or the Joint Global Ocean Flux Study (JGOFS) as well as many national programs have been devoted to understand and assess the ocean's role in the global carbon cycle. Evidence has been provided that the atmosphere and the ocean absorb major amounts of the anthropogenic $\mathrm{CO}_{2}$, whereas the role of the terrestrial biosphere, which is commonly assessed as a closing term of the global carbon balance, still remains unclear. This in part is caused by the uncertainty in the assessment

Correspondence to: $\mathrm{H}$. Thomas

(helmuth.thomas@dal.ca) of the oceanic uptake of anthropogenic $\mathrm{CO}_{2}$ (Sarmiento et al., 2000; Gruber and Keeling, 2001; IPCC, 2001; Orr et al., 2001; Thomas et al., 2001; Takahashi et al., 2002; Sabine et al., 2004). One of the reasons for this uncertainty is the lack of reliable information on the coastal oceans, which hitherto have only barely been considered in the oceanic and global carbon budgets.

Coastal and marginal seas reveal strong biological activity, in part triggered by terrestrial and human impacts, and play an important role in the global carbon cycle by linking the terrestrial, oceanic and atmospheric carbon reservoirs (Gattuso et al., 1998). The high biological activity causes high $\mathrm{CO}_{2}$ fluxes between the coastal and marginal seas and the atmosphere and the adjacent open oceans, respectively. Considering the surface area, coastal seas thus might have a contribution disproportionately high to the open ocean storage of $\mathrm{CO}_{2}$ (Thomas et al., 2004) via a mechanism called the "continental shelf pump" (Tsunogai et al., 1999). High biological activity enables $\mathrm{CO}_{2}$ drawdown from the atmosphere and subsequent export to the subsurface layer. The outflow of these $\mathrm{CO}_{2}$-enriched subsurface waters ultimately transfers the atmospheric $\mathrm{CO}_{2}$ into the intermediate layers of the open ocean. During the last years detailed field studies have been initiated in a few areas such as the East China Sea, the NW European shelf, the Baltic Sea and the North Sea (Chen and Wang, 1999; Thomas et al., 1999, 2003b, 2004; Thomas and Schneider, 1999; Frankignoulle and Borges, 2001; Borges and Frankignoulle, 2002, 2003; Bozec et al., 2005a). However, there is only limited information available on a global scale about these $\mathrm{CO}_{2}$ fluxes (Liu et al., 2000a, b; Chen et al., 2003).

The North Sea is amongst the best-studied coastal areas world-wide with respect to its physical, chemical and biological conditions, since it has been subject to detailed investigations for many decades. Earlier carbon cycle studies in the North Sea were confined to certain near-shore coastal

(C) 2005 Author(s). This work is licensed under a Creative Commons License. 


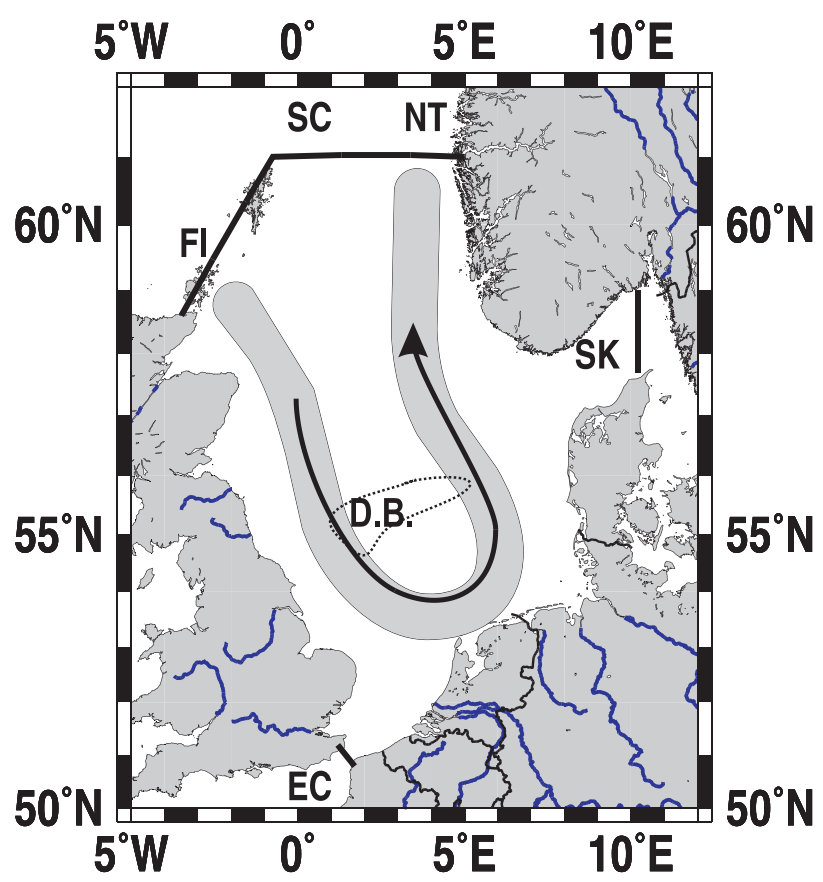

Fig. 1. The Budgeting area for the North Sea. The boundaries of the budgeting area are: English Channel (EC), Skagerrak (SK), Faire Island Channel (FI), Shetland Channel (SC), Norwegian Trench (NT). The arrow indicates the dominant anticlockwise circulation of North Atlantic Ocean water through the North Sea. The location of the Dogger Bank (D.B.) is indicated.

areas such as the German Bight, the Wadden Sea or the Belgian coast (Hoppema, 1991; Frankignoulle et al., 1996; Borges and Frankignoulle, 1999, 2002; Brasse et al., 1999). An early basin-wide pioneer study relied on total alkalinity, dissolved inorganic carbon (DIC) and $\mathrm{pH}$ observations during late spring and provided first insights in the North Sea carbon cycle (Pegler and Kempe, 1988; Kempe and Pegler, 1991). Recently, an intense field study has been carried out covering all seasons with high spatial resolution in order to comprehensively investigate the carbon cycle and its controlling processes in the North Sea (Thomas, 2002; Bozec et al., 2005a; Thomas et al., 2004). Here we establish for the first time a full carbon budget for the North Sea including the $\mathrm{CO}_{2}$ air-sea exchange (Thomas et al., 2004). We rely our study on data from the above program, data from the European Union projects EUROTROPH and BIOGEST, as well as further complementary data.

\section{Site description and methods}

\subsection{Hydrography}

The North Sea (Fig. 1) is located on the north-western European continental shelf with an open northern boundary to the North Atlantic Ocean. In the west and south the North Sea is enclosed by the British Islands, and the European continent (France, Belgium, Netherlands, Germany and Denmark) and the Norwegian West Coast constitute the south-eastern and eastern boundary. The Baltic Sea waters enter the North Sea via the Skagerrak between Denmark and Norway. In the south the English Channel constitutes a further connection to the North Atlantic Ocean. The continuous water exchange across the northern boundary dominates the water budget (OSPARCOM, 2000). Only a minor fraction of this North Atlantic inflow reaches the region south of the Dogger Bank (approx. $55^{\circ} \mathrm{N} 3^{\circ} \mathrm{E}$; Fig. 1), which is controlled by the inputs via the English Channel. As a consequence, the most prevailing feature of the semi-enclosed North Sea is an anticlockwise "u-shaped" circulation of North Atlantic Ocean water entering at the north-western boundaries via the Shetland Channel and the Faire Island Channel and leaving along the Norwegian Trench at the eastern boundary (Fig. 1) with residence times of less than one year (Lenhart and Pohlmann, 1997; Thomas et al., 2003a). For details refer to (OSPARCOM, 2000). A more detailed discussion on the North Sea's hydrography and biogeochemistry is for example given by Lenhart et al. (2004).

\subsection{Bottom topography and carbon cycling}

The bottom topography constitutes a major control of the conditions for the hydrodynamical conditions as well as for biogeochemical cycling in the North Sea (Frankignoulle and Borges, 2001; Bozec et al., 2005a; Thomas et al., 2004). The deeper northern part reveals depths down to approximately $150 \mathrm{~m}$ on the shelf, down to $400 \mathrm{~m}$ in the Norwegian Channel and $700 \mathrm{~m}$ in the Skagerrak. This seasonally stratified part of the North Sea is a rather oceanic system, dominated by the influence of North Atlantic Ocean water. Terrestrial influences play a minor role, riverine inputs from the Scandinavian peninsula and the Baltic Sea inputs "dilute" the North Atlantic Ocean water only in a narrow band along the Norwegian coast. In the northern North Sea stratification enables net export of carbon and nutrient to the deeper layers via sinking of particulate organic matter (POM). In contrast, the water depths south of the Dogger Bank are less than $50 \mathrm{~m}$ deep, and even less than $20 \mathrm{~m}$ deep near the coast. This much smaller, shallow and continuously mixed southern region receives the vast majority of the riverine fresh water supplied to the North Sea. Together with the inputs from the Wadden Sea (Brasse et al., 1999), these inputs exert a significant control of the biogeochemical cycles. The southern region is strongly affected by terrestrial and anthropogenic nutrient inputs (organic and inorganic) and the permanetely mixed water column does not enable export of POM to any deeper layers. The POM is mineralised in the whole water column, causing high turnover of the carbon and nutrients and preventing final burial of POM.

Final burial of POM can be observed only in the deeper basins of the Skagerrak and the Norwegian Channel, whereas 

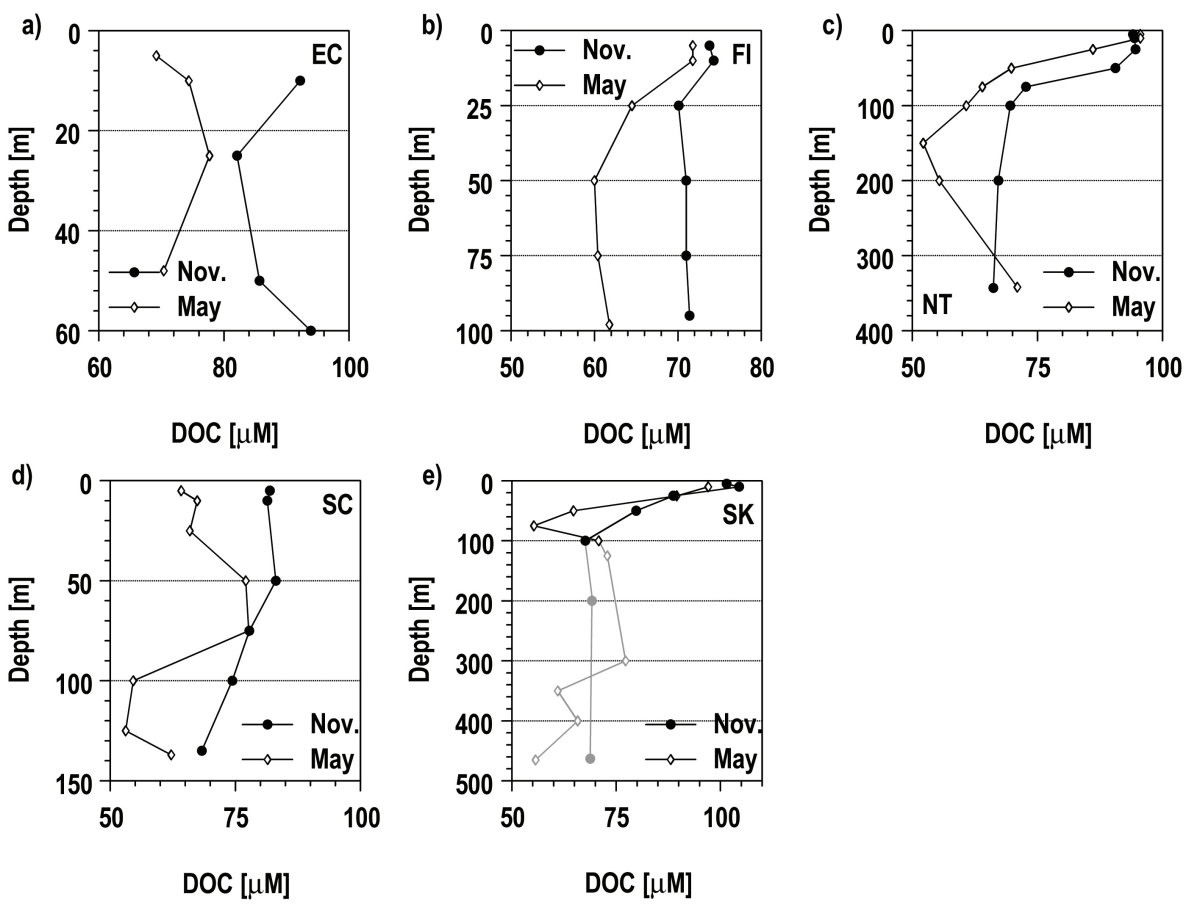

Fig. 2. Dissolved organic carbon (DOC) profiles relied on for establishing the DOC fluxes into and out of the North Sea (Table 1). The profiles are shown for the English Channel (EC) $\left(\mathbf{a}, 51^{\circ} \mathrm{N} 1.5^{\circ} \mathrm{W}\right)$; for the Faire Island Channel (FI) $\left(\mathbf{b}, 60^{\circ} \mathrm{N} 2.5^{\circ} \mathrm{W}\right)$; for the Norwegian Trench (NT) $\left(\mathbf{c}, 61^{\circ} \mathrm{N} 4^{\circ} \mathrm{E}\right)$; for the Shetland Channel (SC) (d, $\left.61^{\circ} \mathrm{N} 0.5^{\circ} \mathrm{E}\right)$ and for the Skagerrak (SK) (e, $\left.58^{\circ} \mathrm{N} 10.24^{\circ} \mathrm{E}\right)$. For the SK station only the upper $100 \mathrm{~m}$ of the profile (black colour) have been considered, whereas the deeper samples (grey colour) have been ignored due to the shallower sill depth in the Skagerrak.

in the remaining parts of the North Sea almost no POM burial occurs. The overall POM burial can be considered as insignificant on an annual time scale and amounts to less than $1 \%$ of the annual primary production (Radach and Lenhart, 1995; De Haas et al., 2002). The lack of ultimate POM burial in both regions of the North Sea has different consequences for the carbon cycling: 1) In the southern part, most of the carbon, fixed as POM by photosynthetic activity, is recycled within the mixed water column or within the sediment surface. On an annual time scale the net $\mathrm{CO}_{2}$ exchange with the atmosphere is small, since the net removal of DIC by photosynthetic activity is negligible except for the period of the spring bloom. 2) In the northern part the stratification enables net removal of $\mathrm{CO}_{2}$ by the export of POM to the subsurface layer and finally DIC export to the North Atlantic Ocean (Bozec et al., 2005a; Thomas et al., 2004).

\subsection{The water budget}

One of the most critical terms in establishing a carbon budget of entire coastal seas or marine areas in general is the water budget, since the gross and net carbon fluxes related to water mass transport usually dominate the budget. Information available on the various components of the water budget of the North Sea (ICES, 1983; Eisma and Kalf, 1987; Otto et al., 1990; Lenhart et al., 1995; Smith et al., 1996; Lenhart and
Pohlmann, 1997) adequately describes the main features of the hydrodynamical circulation. Nevertheless, the exchange flows between the North Atlantic Ocean and the North Sea through the English Channel and across the northern boundary from the different simulations exhibit some discrepancies and are difficult to compare, since they rely on different model structures or forcing conditions. Most critical for our purposes appear to be reliable estimates of the river runoff and the Baltic Sea inflow. The latter one has been reported to be in the range between $1800 \mathrm{~km}^{3} \mathrm{a}^{-1}$ and $3800 \mathrm{~km}^{3} \mathrm{a}^{-1}$ (and one assessment of $300 \mathrm{~km}^{3} \mathrm{a}^{-1}$ ) (Lenhart et al., 1995; Lenhart and Pohlmann, 1997; Smith et al., 1997). However, the (net-) inflow has been reported rather consistently to be on the order of $500 \mathrm{~km}^{3} \mathrm{a}^{-1}$ from various Baltic Sea studies (Stigebrandt, 2001; Thomas et al., 2003b, 2005). In order to overcome this problem, our carbon budget calculations rely on the water budget of Eisma and Kalf (1987), which describes reliably the influx from the Baltic Sea (Stigebrandt, 2001; Thomas et al., 2003b) as well as the magnitude of the riverine inputs (OSPARCOM, 2000). There is notable evidence that the water transport across the northern boundaries can be subdivided into transports in the upper and lower parts of the water column (Lenhart et al., 1995; Pätsch and Radach, 1997). The relative information has been used (Table 1), since it enables us to consider the high resolution DIC and dissolved organic carbon (DOC) data recently obtained. 
Table 1. One-box carbon budget of the North Sea. The budgetting area is $575300 \mathrm{~km}^{2}$, and the water volume $42294 \mathrm{~km}^{3}$. The water budget is according to Eisma and Kalf (1987). The Baltic Sea inputs are taken from Thomas et al. (2003b). The inflow and outflows were separated into upper and lower water column and the corresponding contributions to the entire flux have been given in paranthesis ([ ]) (Pätsch and Radach, 1997). The overall flux across these boundaries has been calculated accordingly. Sedimentation of organic carbon is according to De Haas et al. (2002). DIC and DOC data are taken from Thomas (2002), riverine inputs from Borges et al. $(2005)^{1}$. Positive flows indicate inputs into the North Sea and negative ones flows out of the North Sea. The $\mathrm{CO}_{2}$ air-sea exchange is adopted from Thomas et al. (2004). The uncertainty of the DIC and DOC concentrations is approximately $\pm 1 \mu \mathrm{M}(0.05 \%)$ and $\pm 1 \mu \mathrm{M}(1.25 \%)$, respectively. A $10 \%$ error of both the air-sea flux and the sedimentation estimates has been assumed. The errors given in the last three columns are due to the analytical errors in the DIC and DOC measurements as well as due to the assumed errors in the estimates of the air-sea fluxes and of sedimentation. The unbalanced term is within the range of uncertainty. The heterotrophy increases the DIC pool at the expense of the DOC pool. It does not constitute a net carbon flux across the North Sea boundaries.

\begin{tabular}{|c|c|c|c|c|c|c|}
\hline & \multirow{3}{*}{$\begin{array}{l}\text { Water } \\
\text { input/output } \\
{\left[\mathrm{km}^{3} \mathrm{yr}^{-1}\right]}\end{array}$} & \multicolumn{5}{|c|}{ Carbon } \\
\hline & & \multicolumn{2}{|c|}{ Input/Output concentration } & \multicolumn{2}{|c|}{ Input/Output fluxes } & \multirow[b]{2}{*}{$\begin{array}{c}\text { Total C } \\
{\left[10^{12} \mathrm{~mol} \mathrm{yr}^{-1}\right]}\end{array}$} \\
\hline & & $\begin{array}{c}\mathrm{DIC} \\
{\left[\mu \mathrm{mol} \mathrm{l}^{-1}\right]}\end{array}$ & $\begin{array}{l}\mathrm{DOC} / \mathrm{POC} \\
{\left[\mu \mathrm{mol} \mathrm{l}^{-1}\right]}\end{array}$ & $\begin{array}{c}\text { DIC } \\
{\left[10^{12} \mathrm{~mol} \mathrm{yr}^{-1}\right]}\end{array}$ & $\begin{array}{c}\text { DOC/POC } \\
{\left[10^{12} \mathrm{~mol} \mathrm{yr}^{-1}\right]}\end{array}$ & \\
\hline Baltic Sea & 500 & 2118 & 78 & $1.059( \pm 0.05 \%)$ & $0.039( \pm 1.5 \%)$ & $1.098( \pm 0.08 \%)$ \\
\hline $\begin{array}{l}\text { Atlantic Ocean: } \\
\text { Via English Channel } \\
\text { Via Faire Island and } \\
\text { Pentland Firth } \\
\text { Via Shetland Channel }\end{array}$ & $\begin{array}{l}4900 \\
9000 \\
42000\end{array}$ & $\begin{array}{c}2100 \\
\text { Upper: } 2094[58 \%] \\
\text { Lower: } 2108[42 \%] \\
\text { Upper: } 2102[53 \%] \\
\text { Lower: } 2126[47 \%]\end{array}$ & $\begin{array}{c}80.5 \\
\text { Upper: } 71.2[58 \%] \\
\text { Lower: } 66.0[42 \%] \\
\text { Upper: } 73.9[53 \%] \\
\text { Lower: } 71.6[47 \%]\end{array}$ & $\begin{array}{l}10.290( \pm 0.05 \%) \\
18.898( \pm 0.05 \%) \\
88.758( \pm 0.05 \%)\end{array}$ & $\begin{array}{l}0.395( \pm 1.5 \%) \\
0.621( \pm 1.5 \%) \\
3.058( \pm 1.5 \%)\end{array}$ & $\begin{array}{l}10.685( \pm 0.08 \%) \\
19.520( \pm 0.07 \%) \\
91.812( \pm 0.07 \%)\end{array}$ \\
\hline Rivers & 300 & & & $0.778( \pm 0.05 \%)$ & $0.088( \pm 1.5 \%)$ & $0.866( \pm 0.16 \%)$ \\
\hline $\begin{array}{l}\text { Outflow to the North } \\
\text { Atlantic Ocean via } \\
\text { Norwegian Trench }\end{array}$ & -56700 & $\begin{array}{l}\text { Upper: } 2075 \text { [14\%] } \\
\text { Lower: } 2142 \text { [86\%] }\end{array}$ & $\begin{array}{l}\text { Upper: } 93.4 \text { [14\%] } \\
\text { Lower: } 63.4 \text { [86\%] }\end{array}$ & $-120.92( \pm 0.05 \%)$ & $-3.831( \pm 1.5 \%)$ & $-124.751( \pm 0.07 \%)$ \\
\hline Atmosphere & & $1.38 \mathrm{~mol} \mathrm{C} \mathrm{m}^{-2} \mathrm{yr}^{-1}$ & & $0.794( \pm 10 \%)$ & & $0.794( \pm 10 \%)$ \\
\hline $\begin{array}{l}\text { Sedimentation (marine } \\
\text { part. Organic Carbon) }\end{array}$ & & & $-0.13 \mathrm{~mol} \mathrm{C} \mathrm{m}^{-2} \mathrm{yr}^{-1}$ & & $\begin{array}{c}\text { Shelf: } 0.007 \\
\text { Deep basins: } 0.067\end{array}$ & $-0.073( \pm 10 \%)$ \\
\hline \multicolumn{7}{|l|}{ Subtotals: } \\
\hline Input: & & & & $120.577( \pm 0.08 \%)$ & $4.201( \pm 1.13 \%)$ & $124.779( \pm 0.09 \%)$ \\
\hline Output: & & & & $-120.92( \pm 0.05 \%)$ & $-3.904( \pm 1.5 \%)$ & $-124.824( \pm 0.07 \%)$ \\
\hline Heterotrophy signal & & $0.59( \pm 32 \%) \mathrm{mol} \mathrm{C} \mathrm{m}^{-2}$ & $-0.52( \pm 26 \%) \mathrm{mol} \mathrm{C} \mathrm{m}^{-2}$ & $0.34( \pm 32 \%)$ & $-0.30( \pm 26 \%)$ & \\
\hline Unbalanced: $(0.04 \% \mathrm{o}$ & otal input) & & & & & $0.045( \pm 236 \%)$ \\
\hline
\end{tabular}

\subsection{The carbon budget for the North Sea}

In order to establish a carbon budget for the North Sea, one box was defined with the following boundaries: the Strait of Dover in the South, the Faire Island Channel in the Northwest, the Shetland Channel and the Norwegian Trench in the North along $61^{\circ} \mathrm{N}$ and the Skagerrak in the east (Fig. 1). The carbon fluxes across these boundaries have been computed using the water transports and the corresponding DIC and DOC concentrations. Although POM plays a key role in the carbon metabolism, it only plays a negligible role in importing or exporting carbon across the North Sea boundaries (De

\footnotetext{
${ }^{1}$ Borges, A. V., Thomas, H., Bozec, Y., Abril, G., Schiettecatte, L.-S., Delille, B., Paetsch, J., Alvarez-Salgado, X. A., Brasse, S., Chou, L., Miller, A. E. J., Middelburg, J. J., and Frankignoulle, M.: Fluxes of total alkalinity, dissolved inorganic carbon and dissolved organic carbon out of estuaries to the North Sea, in preparation, 2005 .
}

Haas et al., 2002; Thomas et al., 2005). The fluxes of POM thus have been neglected in the present budget except for the final burial of POM in the North Sea. Riverine inputs and carbon burial have been considered as further sinks or sources to the North Sea box. We assume the system to be in a steady state, i.e. the fluxes into and out of the box balance each other (Eq. 1). Accordingly, the following components of the North Sea carbon fluxes were considered (Eq. 2): inflow with river run-off $\left(F_{R}\right)$, inflow from the Baltic $\left(F_{B}\right)$, inflow from the Atlantic Ocean via the Shetland Channel $\left(F_{S}\right)$, via the Faire Island Channel $\left(F_{F}\right)$ and via the English Channel $\left(F_{E}\right)$, sedimentation $\left(F_{S}\right)$, outflow to the Atlantic Ocean $\left(F_{O}\right)$, net exchange with the atmosphere $\left(F_{A}\right)$. Carbon flows into the box are denoted by a positive sign increasing the carbon content within the box. Carbon flows out of the box are denoted by a negative sign decreasing the carbon content within the box.

$$
\Sigma\left(F_{\text {into the box }}\right)=\Sigma\left(F_{\text {out of the box }}\right)
$$


or

$F_{R}+F_{B}+F_{S}+F_{F}+F_{E}+F_{S}+F_{O}+F_{A}=0$

The required DIC and DOC data (Table 1) have been obtained during the recent North Sea carbon cycle study (Thomas, 2002). The DIC data have been discussed in detail by Bozec et al. (2005a) and Bozec et al. $(2005 b)^{2}$. DOC data for the relevant stations at the North Sea boundaries are shown in Fig. 2. The uncertainty of the DOC data is less than $1 \mu \mathrm{M}$. For each station the average of the observations has been used as an annual average for the budget calculation. Riverine freshwater inputs to the North Sea amount to $300 \mathrm{~km}^{3}$ per year (OSPARCOM, 2000). The riverine DIC and DOC data were compiled from various sources, notably the EU BIOGEST program (Borges et al., 2005 ${ }^{1}$ ). The final inputs were compiled applying the "apparent zero end member" method (Kaul and Froelich, 1984) and upscaled using the "rate curve estimation" method (Cooper and Watts, 2002). The inorganic carbon inputs from the Baltic Sea have been taken from Thomas et al. (2003b). The sedimentation of organic carbon has been estimated according to De Haas et al. (2002) considering only the sedimentation of marine material. The uncertainty of the calculations has been estimated with regard to the analytical uncertainty of the DIC and DOC concentration values as well as with regard to an assumed $10 \%$ uncertainty of each the air-sea flux and sedimentation estimates (Table 1). The errors have been propagated using the formula:

$X=\left(\sum_{i} x_{i}^{2}\right)^{0.5}$

where $X$ denotes the combined error and $x$ the partial errors. The unbalanced term of the budget ( $0.04 \%$ of the total inputs) is within the range of uncertainty ( $0.09 \%$ of the total inputs) and the budget thus can be considered as a closed budget.

\section{Results}

\subsection{Carbon fluxes in the North Sea}

The carbon budget of the North Sea is clearly dominated by the carbon exchange across the northern North Sea boundaries (Fig. 3a, Table 1). The Atlantic Ocean supplies more than $98 \%$ of the carbon: $74 \%$ via the Shetland Channel, $16 \%$ via the Faire Island Channel and 9\% via the English Channel. Moreover, the Baltic Sea supplies approximately $1 \%$ of the carbon. Finally, rivers provide $0.7 \%$ and the atmosphere $0.6 \%$ of the overall carbon import. The dominant role of the North Atlantic Ocean is even more pronounced in exporting carbon from the North Sea. More than $99 \%$ of all carbon

\footnotetext{
${ }^{2}$ Bozec, Y., Thomas, H., Schiettecatte, L.-S., Borges, A. V., Elkalay, K., and deBaar, H. J. W.: Assessment of the processes controlling the seasonal variations of dissolved inorganic carbon in the North Sea, Limnology and Oceanography, submitted, 2005b.
}

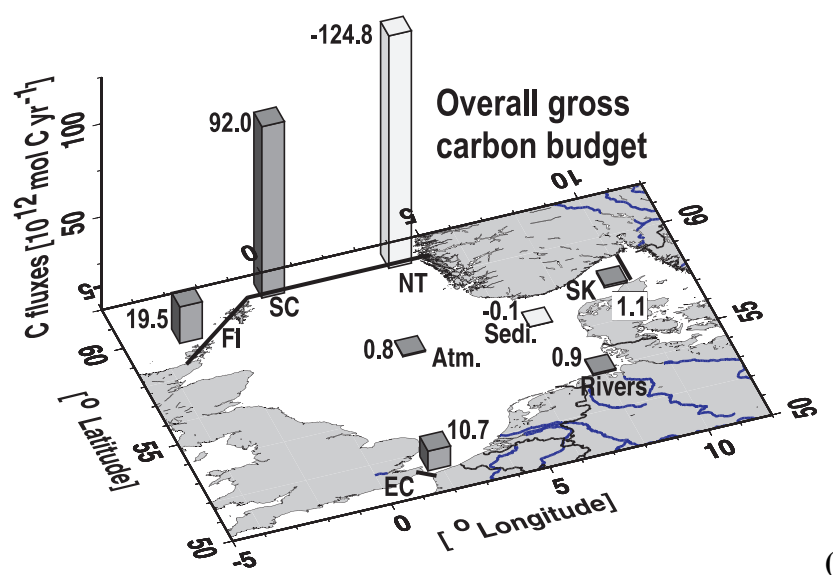

(a)

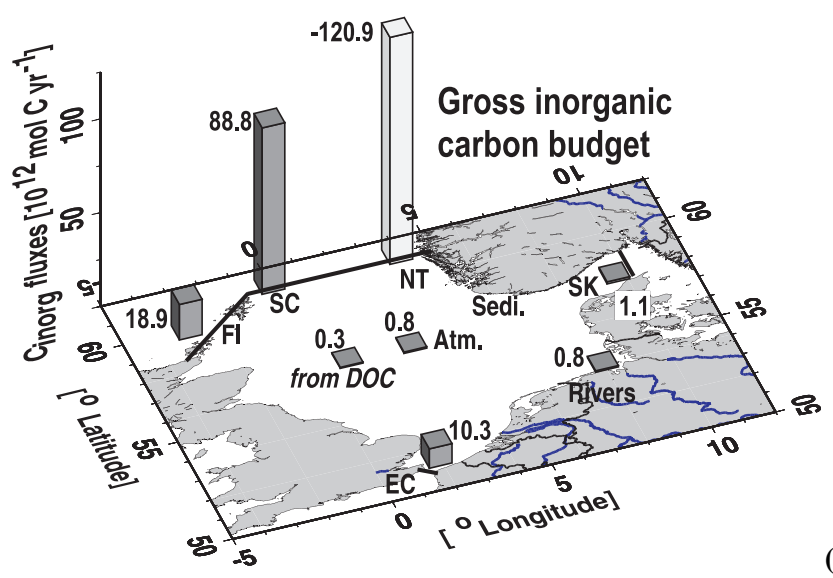

(b)

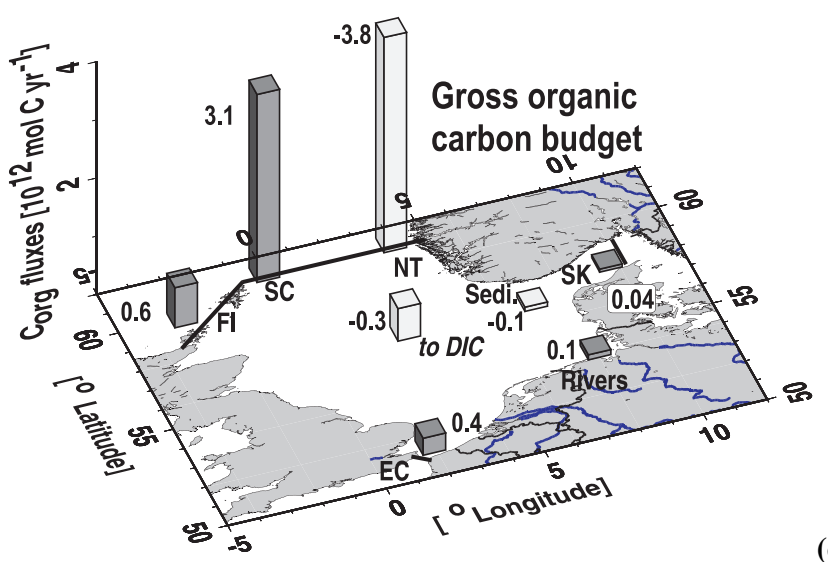

(c)

Fig. 3. Gross carbon budgets of the North Sea. The gross carbon fluxes across the boundaries (see Fig. 1) as well as the fluxes across the air-sea and sediment water interfaces are shown. (a) shows the total (inorganic and organic) gross carbon fluxes and (b) and (c) the gross inorganic and organic carbon fluxes, respectively. The lighter columns denote carbon sinks (negative values) and the darker columns carbon sources (positive values), respectively. Note the different scales of the plots. 


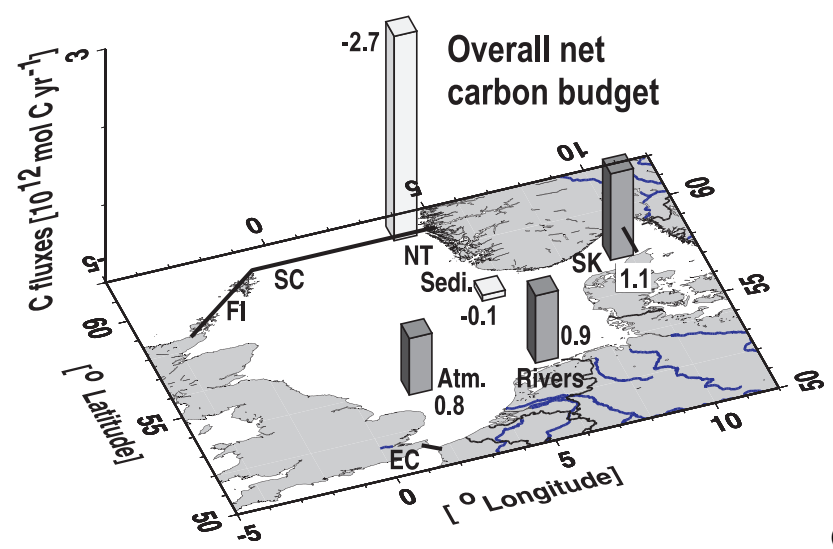

(a)

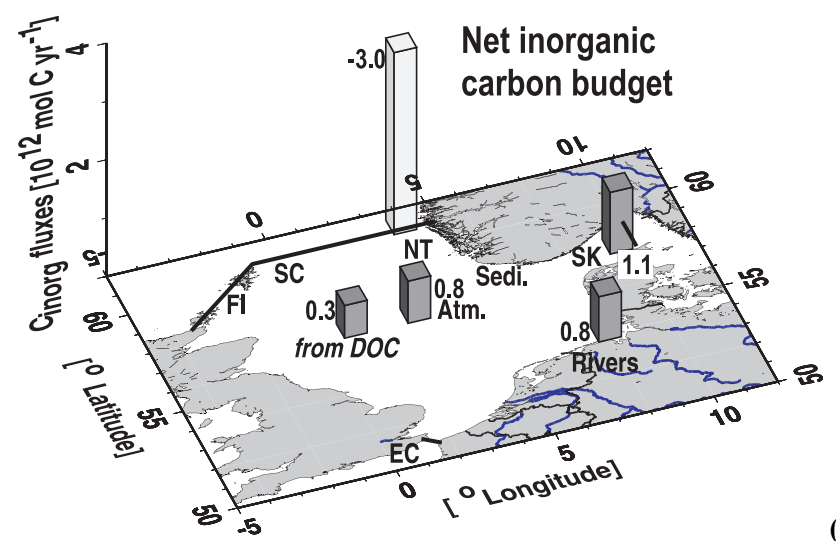

(b)

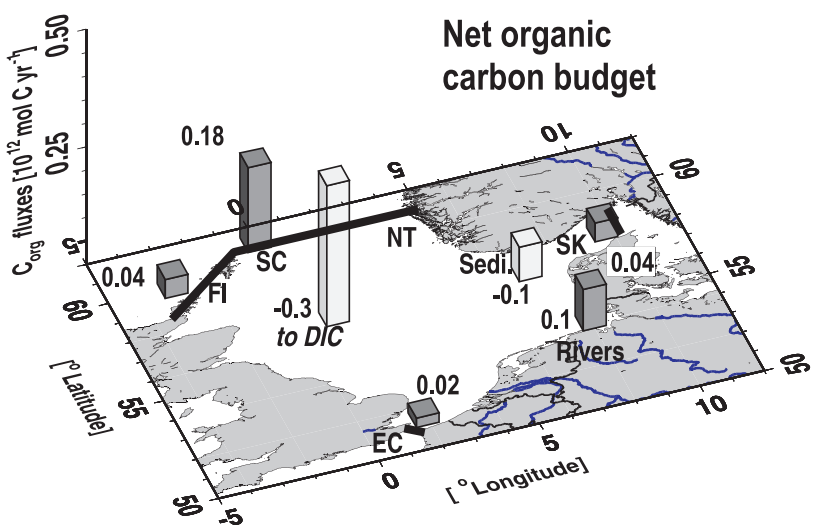

(c)

Fig. 4. Net carbon budgets of the North Sea. The net fluxes are calculated from the gross fluxes minus the carbon imports via Faire Island Channel, Shetland Channel and English Channel representing the circulation of Atlantic Ocean water through the North Sea. The net (residual) carbon fluxes across the boundaries as well as the fluxes across the air-sea and sediment water interfaces are shown. (a): overall net carbon budget; (b): the net budget of inorganic carbon: (c): net budget of organic carbon. The lighter columns denote carbon sinks (negative values) and the darker columns carbon sources (positive values), respectively. Note the different scales of the plots. is exported to the North Atlantic Ocean via the Norwegian Trench, which constitutes the only notable carbon sink of the North Sea over an annual scale. Only less than $1 \%$ of primary production is exported to sediment for burial, which still might play a relevant role over geological time scales. The separation of the gross carbon fluxes into its inorganic (Fig. 3b) and organic (Fig. 3c) fractions shows that inorganic species including (DIC and atmospheric $\mathrm{CO}_{2}$ ) are the major vehicles for the carbon transport. Inorganic species account for $97 \%$ of the inputs and for $97 \%$ of the exports respectively. About $3 \%$ of the carbon is imported to the North Sea as organic carbon and 3\% of the carbon exports leaves the North Sea as DOC and less than $1 \%$ is exported to the sediments. Moreover, the North Sea acts as a sink for organic carbon, i.e. in the view of the budget a part of the organic carbon imported to the North Sea is converted to DIC and thus leave the North Sea as inorganic carbon.

The main features relevant for carbon budgets for coastal areas are more evident when considering the net carbon fluxes, in our case when ignoring the gross fluxes of carbon because of the exchange with the North Atlantic Ocean. For this purpose, the carbon fluxes entering the North Sea via the Faire Island Channel, the Shetland Channel and the English Channel have been subtracted from the carbon outflow via the Norwegian Trench. The riverine inputs, the uptake of atmospheric $\mathrm{CO}_{2}$ and the carbon import from the Baltic Sea can now be identified as the major carbon sources controlling the carbon cycling (Fig. 4a). All are of the similar order of magnitude (Table 1). It is evident that the carbon content of the North Atlantic Ocean is enriched, while it circulates through the North Sea, by the three suppliers (the atmosphere, the Baltic Sea and the rivers). The overall enrichment of the carbon content of the Atlantic Ocean water amounts to $2.7310^{12} \mathrm{~mol} \mathrm{C} \mathrm{yr}^{-1}$, which is approximately $2 \%$ of the initial carbon content or - related to the North Sea surface $4.8 \mathrm{~mol} \mathrm{C} \mathrm{yr}^{-1} \mathrm{~m}^{-2}$. The atmosphere represents $29 \%$ of this enrichment, the Baltic Sea $40 \%$ and the riverine input $31 \%$.

A closer look to the net fluxes of the inorganic and organic species shows that the inorganic carbon pool is increased not only by the atmosphere, the Baltic Sea and the rivers, but also from the North Sea DOC pool (Fig. 4b). Considering the observed increase of DIC between the inflowing and outflowing waters, it has been shown that the uptake of atmospheric $\mathrm{CO}_{2}$ and the "internal" conversion of DOC to DIC contribute almost equally to the DIC increase. Approximately $9 \%$ of the entire DOC inputs are transferred to the inorganic pool, which is equivalent to 4 times the riverine organic carbon inputs. The major difference between both DIC sources is that the conversion of DOC to DIC does not constitute a net carbon flux, whereas the uptake of atmospheric $\mathrm{CO}_{2}$ constitutes a net import of carbon. About $10 \%$ of the latter are transferred to the sediments and $90 \%$ to the North Atlantic Ocean by the continental shelf pump (Bozec et al., 2005a; Thomas et al., 2004; Table 1). The North Sea thus acts as a highly efficient continental shelf pump. For the organic carbon pool 
(Fig. 4c) the situation is different. The Atlantic Ocean acts as the major source of DOC in the North Sea, while rivers and the Baltic Sea play a rather modest role in the organic carbon budget of the North Sea. Still, these inputs are biogeochemically significant, especially in the southern part, which receives the largest part of the river runoff. Final POM burial acts as a minor sink of organic carbon and the loss of DOC to the DIC pool constitutes the major sink for DOC.

\subsection{The trophic state of the North Sea}

The trophic status of marine areas can be defined with regard to the production or consumption of organic matter (Odum, 1983; Smith and Hollibaugh, 1993; Gattuso et al., 1998): autotrophic systems are net-producers of organic matter at the expense of inorganic nutrients and carbon: i.e. gross primary production $(G P P)$ is larger than respiration $(R)$. These systems can export all or part of the excess organic carbon. In contrast, in heterotrophic systems $R$ dominates $G P P$, i.e. these systems are net-consumers of organic matter and release inorganic nutrients and carbon. In the "ideal" situation of a real 1-box marine ecosystem, the atmosphere fuels the carbon demand of an autotrophic system unless there is a further inorganic carbon source such as rivers available. Depending on the initial conditions of the water, these systems reveal enhanced uptake of atmospheric $\mathrm{CO}_{2}$ or in the case of supersaturated waters, any $\mathrm{CO}_{2}$ release to the atmosphere will be diminished. Similarly, heterotrophic 1-box systems require an organic carbon source and produce inorganic carbon. Accordingly, these systems reveal enhanced $\mathrm{CO}_{2}$ release to the atmosphere or in case of undersaturated waters, any $\mathrm{CO}_{2}$ uptake from the atmosphere will be diminished. As examples for such 1-box systems might serve the permanently well-mixed systems like the English Channel (Borges and Frankignoulle, 2003) and the Southern Bight of the North Sea (Thomas et al., 2004) or the south-western Baltic Proper (Thomas and Schneider, 1999), all weak sources of atmospheric $\mathrm{CO}_{2}$. Also, near-shore coastal regions influenced by anthropogenic and/or terrestrial organic and inorganic carbon inputs such as estuaries and estuarine plumes are sources of $\mathrm{CO}_{2}$ (Frankignoulle et al., 1998; Borges and Frankignoulle, 2002; Borges et al., 2003).

Complications arise from the transfer of these definitions, originally introduced with regard to individual species, onto marine ecosystems with more than one compartment, since production and respiration processes may be separated in space. In stratified systems, autotrophic processes generally dominate in the surface layer causing the $\mathrm{CO}_{2}$ uptake and heterotrophic processes dominate the subsurface layer (Bozec et al., 2005a; Thomas et al., 2004) causing in the case of the North Sea the net DIC export to the North Atlantic Ocean. Full carbon (this study) and organic carbon and nutrient (Lenhart et al., 2004) budgets indicate the entire North Sea as a heterotrophic system, which still acts as a sink for atmospheric $\mathrm{CO}_{2}$. As further examples for such systems might serve seasonally stratified regions such as the Gulf of Biscay (Frankignoulle and Borges, 2001), or permanently stratified regions such as the Baltic Sea (Thomas and Schneider, 1999). The opposite situation is often found in upwelling systems, which commonly are strong producers and exporters of organic matter, however the autotrophic activity is masked by DIC-rich upwelled waters causing a $\mathrm{CO}_{2}$ release to the atmosphere as for example in the Arabian Sea (Lendt et al., 2003).

These complications are also evident when comparing the findings of the carbon budget presented here with the findings by Smith et al. (1997), who report an autotrophic state of the southern North Sea, this in contrast to the findings of Borges and Frankignoulle (2003), Thomas et al. (2004) and of the present study. The major differences between their (Smith et al., 1997) and our present assessment are firstly the area covered and secondly the data referred to. Smith et al.'s (1997) budget exclude the northern areas of the North Sea, of which deeper layers apparently host a significant part of the heterotrophic activity. This line of argument is supported by Lenhart et al. (2004), who assessed the trophic state employing an ecosystem model in order to establish an organic carbon balance. They report a general heterotrophic state of the North Sea, which is of the same order of magnitude than the one reported here. Lenhart et al. (2004) were able to provide detailed figures for the northern and southern North Sea, showing the dominating heterotrophy in the northern North Sea and autotrophy in the southern part, thus confirming Smith et al. (1997). However, our study can only make a statement on the entire North Sea system, while no details can be given for the southern part solely, since we apply a one-box budget. Moreover, the different findings for the southern North Sea by Smith et al. (1997) on the one side and the findings of Borges and Frankignoulle (2003) and of Thomas et al. (2004) on the other side might also be caused by the application of different data $\left(\mathrm{PO}_{4} \mathrm{vs}\right.$. inorganic and organic carbon data, respectively). Our budget shows that the heterotrophy of the entire North Sea is to a large extent related to the degradation of DOC imported from the North Atlantic Ocean. This feature obviously could not be captured in the Smith et al.'s (1997) budget based on inorganic phosphorous mass balance approach. Problems with applying nutrient data for the assessment of the trophic state have for example been reported by Thomas et al. (2003b).

It has been shown that the speciation of the inputs into these systems from rivers or adjacent basins - for example the North Atlantic Ocean (see above) - plays an important role in determining the trophic state. Primarily inorganic inputs support autotrophic activity, whereas primarily organic inputs support heterotrophic activity (Thomas et al., 2003b; Vichi et al., 2004; Lenhart et al., 2004). While the riverine inputs are of higher relevance for estuaries, near-shore areas and narrow shelves (Frankignoulle et al., 1998; Borges and Frankignoulle, 2002; Borges et al., 2003), these inputs become less relevant, the more oceanic systems become. 

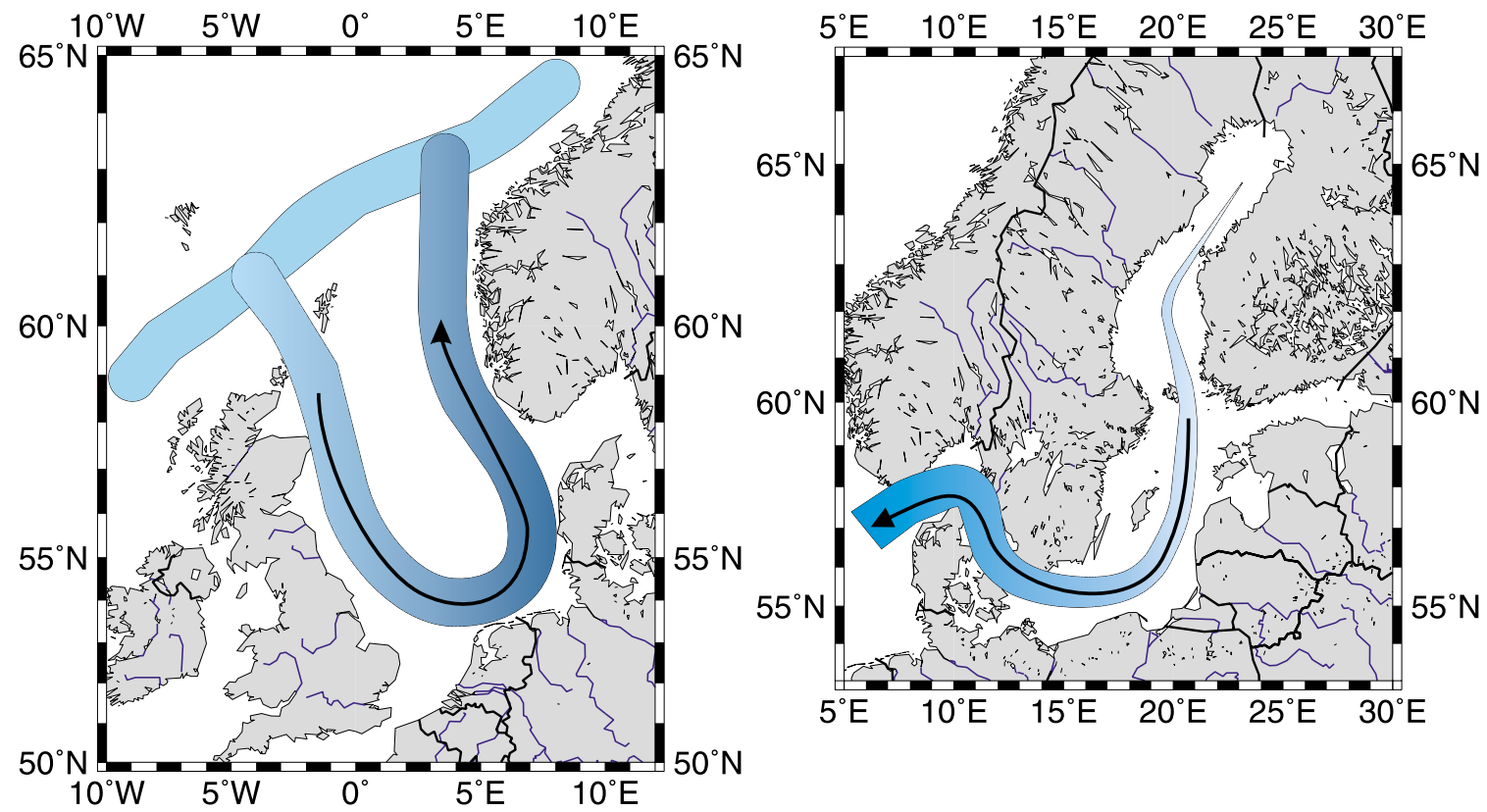

Fig. 5. Different operational modes of the continental shelf pump: the bypass pump in the North Sea (a) and the injection pump in the Baltic Sea (b).

\subsection{Discussion of the budget}

The error estimate given in Table 1 is based on the analytical uncertainty of DIC and DOC as well as on the assumed errors of the sedimentation and air-sea flux estimates. This error term does not take into account any uncertainty related to the water budget. Moreover, a seasonal data coverage could not be achieved for all stations and parameters. The error estimate (Table 1) thus reflects the lower bound of the uncertainty. As indicated in section two, the carbon budget is closely related to the water budget of the North Sea. Despite the fact that the water exchange with the North Atlantic Ocean dominates both the carbon and the water budget, the carbon budget is highly sensitive to the net water fluxes from the land and the Baltic Sea. While the water import from the Baltic Sea is well established (e.g. Stigebrandt, 2001), available information on the riverine inputs must be carefully evaluated. For example the runoff of the major rivers amounts to approximately $130 \mathrm{~km}^{3} \mathrm{yr}^{-1}$, whereas the total river runoff to the North Sea amounts to $300 \mathrm{~km}^{3} \mathrm{yr}^{-1}$ (OSPARCOM, 2000). Given the comparable magnitude of the net players of the carbon budget (Fig. 3), a reliable knowledge on these fluxes is essential. This also holds true for the inflow from the Baltic Sea, which has been overestimated in all modelling studies (see Sect. 2.2). In order to derive the net carbon fluxes, a reliable knowledge of the gross fluxes, i.e. on the carbon exchange between North Sea and North Atlantic Ocean is required. The assessment of the gross flows benefited from the high resolution carbon cycle data set (Thomas, 2002) and allowed to unravel the net flows from the much larger gross flows.

\section{The continental shelf pump: operational modes in the North Sea and the adjacent Baltic Sea}

The carbon budget describes the North Sea as an overall heterotrophic semi-enclosed sea. The main feature is the circulation of Atlantic Ocean water through the North Sea, of which carbon content is increased during this transport. Major sources increasing the carbon contents of the Atlantic Ocean water are the Baltic Sea, the rivers and the atmosphere. The uptake of atmospheric $\mathrm{CO}_{2}$ by the North Sea amounts to $1.38 \mathrm{~mol} \mathrm{C} \mathrm{m} \mathrm{yr}^{-1}$, of which more than $90 \%$ are transferred to the Atlantic Ocean. The continental shelf pump is thus more effective than in the Baltic Sea, which exports approximately $43 \%$ of the $\mathrm{CO}_{2}$ air-sea flux to the North Sea and the remaining 57\% to the sediments (Thomas et al., 2003b). This can be explained by different bottom topographic and hydrographic conditions, which cause different operational modes for the continental shelf pump. The brackish Baltic Sea rather serves as a collecting basin for fresh water, which finally is transported following a "oneway road" via the Skagerrak to the North Sea. The permanent halocline and the deeper basins enable effective export of organic matter from the surface layer, which is equivalent to $\mathrm{CO}_{2}$ draw-down from the atmosphere. Once this carbon escapes the surface layer it can hardly be exported to the North Sea and only the remaining part in the surface layers is available to the continental shelf pump. In contrast, the North Sea reveals almost no carbon preservation in sediments, which ultimately implies that the entire $\mathrm{CO}_{2}$ drawdown caused by biological activity is available for export to the Atlantic Ocean. The relatively short flushing time of the 
North Sea and its bottom topography play a major role in preventing sedimentation and accumulation of POM (De Haas et al., 2002). Once the $\mathrm{CO}_{2}$ has been taken up by the North Sea, it is rapidly exported to the Atlantic Ocean. The North Sea thus can be seen as a bypass pump (Fig. 5a), which increases the carbon content of Atlantic Ocean water while it is circulated through the North Sea. In contrast, the Baltic Sea rather acts as an injection pump (Fig. 5b), which injects "new" water and corresponding carbon loads to the adjacent aquatic system, which is in this case the North Sea.

Acknowledgements. The excellent co-operation of the captains and the crews of "RV Pelagia" is gratefully acknowledged. This study has been encouraged by and contributes to the LOICZ core project of the IGBP and to CARBO-OCEAN, an integrated project of the European Union (contract no. 511176-2). It has been supported by the Netherlands Organisation for Scientific Research (NWO), grants no. 810.33.004 and 014.27.001, the Dutch-German bilateral co-operation NEBROC, the Belgium Federal Office for Scientific, Technical and Cultural Affairs (CANOPY project, EV/03/20) and EU EUROTROPH project (EVK3-CT-2000-00040) A. V. Borges and M. Frankignoulle are, respectively, a post-doctoral researcher and a senior research associate at the FNRS. An earlier version of this paper greatly benefited from two anonymous reviewers' and the editor's comments. This is MARE contribution $\mathrm{n}^{\circ} 0061$.

Edited by: J.-P. Gattuso

\section{References}

Borges, A. V. and Frankignoulle, M.: Daily and seasonal variations of the partial pressure of $\mathrm{CO}_{2}$ in surface seawater along Belgian and southern Dutch coastal areas, J. Marine Sys., 19, 251-266, 1999.

Borges, A. V. and Frankignoulle, M.: Distribution and air-water exchange of carbon dioxide in the Scheldt plume off the Belgian coast, Biogeochemistry, 59, 41-67, 2002.

Borges, A. V. and Frankignoulle, M.: Distribution of surface carbon dioxide and air-sea exchange in the English Channel and adjacent areas, J. Geophys. Res., 108, 1-14, 2003.

Borges, A. V., Djenidi, S., Lacroix, G., Théate, J., DeLille, B., and Frankignoulle, M.: Atmospheric $\mathrm{CO}_{2}$ flux from mangrove surrounding waters, Geophys. Res. Lett., 30, 12-11/12-14, 2003.

Bozec, Y., Thomas, H., Elkalay, K., and De Baar, H.: The continental shelf pump in the North Sea - evidence from summer observations, Marine Chemistry, 93, 131-147, $2005 \mathrm{a}$.

Brasse, S., Reimer, A., Seifert, R., and Michaelis, W.: The influence of intertidal mudflats on the dissolved inorganic carbon and total alkalinity distribution in the German Bight, southeastern North Sea. Journal of Sea Research, 42, 93-103, 1999.

Chen, C.-T. A. and Wang, S.-L.: Carbon, alkalinity and nutrient budgets on the East China Sea continental shelf, J. Geophys. Res., 104, 20 675-20 686, 1999.

Chen, C.-T. A., Liu, K.-K., and MacDonald, R.: Continental margin exchanges, in: Ocean Biogeochemistry: A JGOFS synthesis, edited by: Fasham, M. J. R., Springer, 53-97, 2003.
Cooper, D. M. and Watts, C. D.: A comparison of river load estimation techniques: application to dissolved organic carbon, Environmetrics, 13, 733-750, 2002.

De Haas, H., Van Weering, T. C. E., and De Stigter, H.: Organic carbon in shelf seas: sinks or sources, processes and products, Continental Shelf Research, 22, 691-717, 2002.

Eisma, D. and Kalf, J.: Dispersal, concentration and deposition of suspended matter in the North Sea, J. Geological Society of London, 161-178, 1987.

Frankignoulle, M. and Borges, A. V.: European continental shelf as a significant sink for atmospheric carbon dioxide, Global Biogeochem. Cycles, 15, 569-576, 2001.

Frankignoulle, M., Bourge, I., Canon, C., and Dauby, P.: Distribution of surface seawater partial $\mathrm{CO}_{2}$ pressure in the English Channel and in the Southern Bight of the North Sea, Continental Shelf Research, 16, 381-395, 1996.

Frankignoulle, M., Abril, G., Borges, A., Bourge, I., Canon, C., DeLille, B., Libert, E., and Théate, J.-M.: Carbon dioxide emission from European estuaries, Science, 282, 434-436, 1998.

Gattuso, J.-P., Frankignoulle, M., and Wollast, R.: Carbon and carbonate metabolism in coastal aquatic ecosystems, Annual Reviews of Ecological Systems, 29, 405-434, 1998.

Gruber, N. and Keeling, C. D.: An improved estimate of the isotopic air-sea disequilibrium of $\mathrm{CO}_{2}$ : Implications for the oceanic uptake of anthropogenic $\mathrm{CO}_{2}$, Geophys. Res. Lett., 28, 555-558, 2001.

Hoppema, J. M. J.: The seasonal behaviour of carbon dioxide and oxygen in the coastal North Sea along the Netherlands, Netherlands Journal of Sea Research, 28, 167-179, 1991.

ICES: Flushing times of the North Sea, ICES Cooperative Research Report, 125, 1983.

IPCC: The scientific basis, in: Contribution of Working Group I to the Third Assessment Report of the Intergovernmental Panel on Climate Change, edited by: Johnson, C. A., Cambridge University Press, New York, USA, 2001.

Kaul, L. and Froelich, P.: Modelling estuarine nutrient biogeochemistry in a simple system, Geochim Cosmochim Acta, 48, 14171433, 1984.

Kempe, S. and Pegler, K.: Sinks and sources of $\mathrm{CO}_{2}$ in coastal seas: the North Sea, Tellus, 43B, 224-235, 1991.

Lendt, R., Thomas, H., Hupe, A., and Ittekkot, V.: Response of the near-surface carbonate system of the northwestern Arabian Sea to the southwest monsoon and related biological forcing, J. Geophys. Res., 108, 15-11/15-14, 2003.

Lenhart, H. and Pohlmann, T.: The ICES-boxes approach in relation to results of a North Sea circulation model, Tellus, 49A, 139160, 1997.

Lenhart, H. J., Radach, G., Backhaus, J. O., and Pohlmann, T.: Simulations of the North Sea circulation, its variability, and its implementation as hydrodynamical forcing in ERSEM, Netherlands Journal of Sea Research, 33, 271-299, 1995.

Lenhart, H. J., Pätsch, J., Kühn, W., Moll, A., Pohlmann, T.: Investigation on the trophic state of the North Sea for three years (1994-1996) simulated with the ecosystem model ERSEM - the role of a sharp NAOI decline, Biogeosciences Discuss., 1, 725753, 2004,

SRef-ID: 1810-6285/bgd/2004-1-725.

Liu, K.-K., Iseki, K., and Chao, S.-Y., Continental margin carbon fluxes, in: The Changing Ocean Carbon Cycle: A midterm syn- 
thesis of the Joint Global Ocean Flux Study, edited by: Field, J. G., Cambridge University Press, Cambridge, 187-239, 2000a.

Liu, K.-K., Atkinson, L., Chen, C. T. A., Gao, S., Hall, J., MacDonald, R., Talaue McManus, L., and Quinones, R.: Exploring continental margin carbon fluxes on a global scale, EOS, 81, 641-644, 2000 b.

Odum, E. P.: Basic Ecology, Saunders College Publishing, Philadelphia, 1983.

Orr, J. C., Maier-Reimer, E., Mikolajewicz, U., Monfray, P., Sarmiento, J. L., Toggweiler, J. R., Taylor, N. K., Palmer, J., Gruber, N., Sabine, C. L., Le Quéré, C., Key, R. M., and Boutin, J.: Estimates of anthropogenic carbon uptake from four threedimensional global ocean models, Global Biogeochem. Cycles, 15, 43-60, 2001.

OSPARCOM: Quality Status Report 2000 - Region II Greater North Sea, OSPAR Commission, London, 136, 2000.

Otto, L., Zimmerman, J. T. F., G. Furnes, K., Mork, M., Saetre, R., and Becker, G.: Review of the physical oceanography of the North Sea, Netherlands Journal of Sea Research, 26, 161-238, 1990.

Pätsch, J. and Radach, G.: Long-term simulation of the eutrophication of the North Sea: Temporal development of nutrients, chlorophyll and primary production in comparison to observations, J. Sea Research, 275-310, 1997.

Pegler, K. and Kempe, S.: The carbonate system of the North Sea: determination of alkalinity and $\mathrm{TCO}_{2}$ and calculation of $\mathrm{PCO}_{2}$ and $\mathrm{Sl}_{\text {cal }}$ (spring 1986), Mitt. Geol.-Paläont. Inst. Univ. Hamburg, 65, 35-87, 1988 .

Radach, G. and Lenhart, H. J.: Nutrient dynamics in the North Sea: fluxes and budgets in the water column derived from ERSEM, Netherlands Journal of Sea Research, 33, 301-335, 1995.

Sabine, C. L., Feely, R. A., Gruber, N., Key, R. M., Lee, K., Bullister, J. L., Wanninkhof, R., Wong, C. S., Wallace, D. W. R., Tilbrook, B., Millero, F. J., Peng, T.-H., Kozyr, A., Ono, T., and Rios, A. F.: The Oceanic Sink for Anthropogenic CO2, Science, 305, 367-371, 2004.

Sarmiento, J. L., Monfray, P., Maier-Reimer, E., Aumont, O., Murnane, R. J., and Orr, J. C.: Sea-air $\mathrm{CO}_{2}$ fluxes and carbon transport: A comparison of three ocean general circulation models, Global Biogeochem. Cycles, 14, 1267-1281, 2000.

Smith, J. A., Damm, P. E., Skogen, M. D., Flather, R. A., and Pätsch, J.: An investigation into the variability of circulation and transport on the north-west European shelf using three hydrodynamic models, Deutsche Hydrographische Zeitschrift, 48, 325348, 1996

Smith, S. V. and Hollibaugh, J. T.: Coastal metabolism and the ocean organic carbon balance, Rev. Geophys., 31, 75-89, 1993.
Smith, S. V., Boudreau, P. R., and Ruardij, P.: NP Budget for the Southern North Sea, http://data.ecology.su.se/mnode/Europe/ NorthSea/NORTHSEA.HTM, 1997.

Stigebrandt, A.: Physical Oceanography of the Baltic Sea, in: A System Analysis of the Baltic Sea, edited by: Larsson, P., Springer, Berlin Heidelberg, 19-74, 2001.

Takahashi, T., Sutherland, S. C., Sweeney, C., Poisson, A., Metzl, N., Tilbrook, B., Bates, N. R., Wanninkhof, R., Feely, R. A., Sabine, C. L., Olafsson, J., and Nojiri, Y.: Global sea-air CO2 flux based on climatological surface ocean pCO2, and seasonal biological and temperature effects, Deep-Sea Res. II, 49, 16011622, 2002.

Thomas, H.: Shipboard report of the RV Pelagia cruises 64PE184. 64PE187, 64PE190 and 64PE195, Royal Netherlands Institute for Sea Research, Texel, NL, 63, 2002.

Thomas, H. and Schneider, B.: The seasonal cycle of carbon dioxide in the Baltic Sea surface waters, J. Marine Sys., 22, 53-67, 1999.

Thomas, H., England, M. H., and Ittekkot, V.: An off-line 3D model of anthropogenic $\mathrm{CO}_{2}$ uptake by the oceans, Geophys. Res. Lett., 28, 547-550, 2001.

Thomas, H., Gattuso, J.-P., and Smith, S. V.: Coastal Biogeochemistry at the EGS-AGU-EUG Joint Assembly, Nice, France, 6-11 April 2003, LOICZ newsletter, 28, 2003a.

Thomas, H., Pempkowiak, J., Wulff, F., and Nagel, K.: Autotrophy, nitrogen accumulation and nitrogen limitation in the Baltic Sea: a paradox or a buffer for eutrophication?, Geophys. Res. Lett., 30, 2130, doi:2110.1029/2003GL017937, 2003b.

Thomas, H., Ittekkot, V., Osterroht, C., and Schneider, B.: Preferential recycling of nutrients - the ocean's way to increase new production and to pass nutrient limitation?, Limnology and Oceanography, 44, 1999-2004, 1999.

Thomas, H., Bozec, Y., Elkalay, K., and De Baar, H.: Enhanced open ocean storage of $\mathrm{CO} 2$ from shelf sea pumping, Science, 304, 1005-1008, 2004.

Thomas, H., Pempkowiak, J., Wulff, F., and Nagel, K.: Carbon and nutrient budgets of the Baltic Sea, in: Carbon and nutrient fluxes in global continental margins, edited by: Talaue-McManus, L., Springer, New York, 2005.

Tsunogai, S., Watanabe, S., and Sato, T.: Is there a "continental shelf pump" for the absorption of atmospheric $\mathrm{CO}_{2}$ ?, Tellus, 51B, 701-712, 1999.

Vichi, M., Ruardij, P., and Baretta, J. W.: Link or sink: a modelling interpretation of the open Baltic biogeochemistry, Biogeosciences, 1, 79-100, 2004,

SRef-ID: 1726-4189/bg/2004-1-79. 